\title{
The digestion of bulbils (Polygonum viviparum L.) and berries (Vaccinium myrtillus L. and Empetrum sp.) by captive ptarmigan (Lagopus mutus)
}

\author{
By R. MOSS \\ Institute of Terrestrial Ecology, Blackhall, Banchory, Kincardineshire $A_{3}{ }_{3} P S$ \\ AND J. A. PARKINSON \\ Institute of Terrestrial Ecology, Merlewood Research Station, Grange-over-Sands, \\ Lancashire
}

(Received I9 April I974-Accepted I October 1974)

\begin{abstract}
I. The digestion of three foods favoured by ptarmigan (Lagopus mutus) in the wild was studied using captive birds.

2. Bulbils of Polygonum viviparum L. were a good source of metabolizable energy, protein and phosphorus, but were deficient in sodium. Berries of Vaccinium myrtillus $\mathbf{L}$. were the most digestible of the three foods, contained enough protein and $\mathrm{P}$ for maintenance, but were probably deficient in $\mathrm{Na}$. A diet of Empetrum sp. berries caused the birds to be in negative nitrogen and $\mathrm{P}$ balance, but provided adequate $\mathrm{Na}$. Both species of berries were rich sources of soluble carbohydrate.

3. In the wild, ptarmigan eat a mixed diet, which presumably provides adequate $\mathrm{Na}$, protein and $\mathbf{P}$.

4. The relative proportions of the various end-products of $\mathrm{N}$ metabolism varied according to the protein content of the food. With the diet of Vaccinium berries ( I I $\mathrm{g} \mathrm{N} / \mathrm{kg}$ dry matter) roughly equal amounts of ammonium salts and urates were excreted. With Polygonum bulbils $(29 \mathrm{~g} \mathrm{~N} / \mathrm{kg}$ dry matter) the quantities of ammonium salts and urates excreted were similar to those with Vaccinium berries, but some urea was also excreted and about half the $\mathrm{N}$ in the birds' droppings was in an unidentified form.

5. When eating Empetrum berries, ptarmigan digested lignin and tannins and excreted ornithurates. The benzoic acid moiety of the ornithuric acid molecule may have been derived partly from the digested lignin and tannins.
\end{abstract}

Bulbils of Polygonum viviparum L. are a favourite food of rock ptarmigan (Lagopus mutus (Montin)) in East Greenland (Gelting, 1937) and Iceland (Gardarsson \& Moss, 1970). They also eat many berries of Empetrum sp. in Iceland (Gardarsson \& Moss, 1970) and Vaccinium myrtillus L. in Scotland (Watson, 1964). In this paper we examine the digestion of these foods by captive ptarmigan.

The gross morphology of the digestive system in the ptarmigan is similar to that of the closely related red grouse (Lagopus lagopus scoticus (Lath.)), described in detail by Wilson (I9II) and summarized by Moss \& Parkinson (1972). The main difference between the species is that the ptarmigan is a smaller bird; a typical Scottish cock weighs about $500 \mathrm{~g}$ and the red grouse $600 \mathrm{~g}$. 


\section{EXPERIMENTAL}

\section{Birds and their management}

Ptarmigan were hatched from eggs collected in the Cairngorm mountains of Scotland, and reared in captivity (Moss, 1969). Fully grown birds were kept indoors with natural lighting, in the winters of $1968-9$ and $1970-1$, in individual cages measuring $0.6 \times 0.6 \times 0.6 \mathrm{~m}$. The droppings were collected daily on plastic-covered trays under floors of $12.5 \mathrm{~mm}$ wire mesh. The birds' normal diet was grouse maintenance pellets (Rank, Hovis, MacDougall Agriculture (Caledonia) Ltd, Riverside Drive, Aberdeen $\mathrm{AB} 98 \mathrm{DN}$ ) with a supplementary bundle of fresh heather (Calluna vulgaris L. Hull) twice weekly. Water and granite grit were freely available, except during the trials, when grit was not provided for a few days prior to and during the collection of droppings. This reduced the amount of grit which had to be removed from the droppings.

During the trials, the birds were weighed each day. Initially, the food was a mixture of grouse maintenance pellets and bulbils or berries $(\mathrm{r}: \mathrm{I}, \mathrm{v} / \mathrm{V})$. When the latter were being eaten readily, the proportion of pellets was reduced over a period of 7 -Io d until the diet consisted entirely of the test food. A further $5^{-7} \mathrm{~d}$ was allowed so that the birds could become accustomed to their new diet and the intention was then to collect the droppings and weigh the amount of food eaten for a final period of $5 \mathrm{~d}$. This was done in the trials with berries. However, after ro d on the bulbils alone, the birds suddenly started to eat less, their caecal droppings became watery in appearance and the birds began to lose weight. They were then provided with a o. I M- $\mathrm{NaCl}$ solution instead of distilled water and food intake, the appearance of the droppings and the birds' weight all returned to normal. The $\mathrm{NaCl}$ concentration was then reduced to $0.05 \mathrm{M}$ and the droppings were collected for $5 \mathrm{~d}$.

\section{Experimental procedures}

Sampling. 'Two kinds of droppings were produced by the birds eating bulbils: (I) hard, cylindrical 'woody' droppings with conspicuous white caps and (2) soft, shapeless, khaki-brown 'caecal' (i.e. non-woody) droppings. The two sorts of droppings were collected separately as far as possible, although a small proportion of the caecal droppings was unavoidably included with the woody droppings.

The birds eating berries produced large quantities of watery urine. This was not surprising as the daily intake of berries contained about $200 \mathrm{ml}$ water. The caecal and woody droppings were purple and liquid but only the woody droppings contained undigested seeds. No attempt was made to separate these droppings from each other or from the urine.

Samples of food and all the droppings were stored at $-15^{\circ}$ until required for analysis when they were freeze-dried and milled to pass through a $\mathrm{I} \mathrm{mm}$ mesh sieve. Sub-samples were dried to constant weight at $100^{\circ}$ to determine the dry matter (DM) content. 
Estimation of retention ratios. The retention ratio

$$
\left(\frac{\text { amount eaten - amount excreted in droppings (faeces and urine) }}{\text { amount eaten }}\right)
$$

was determined for each dietary constituent. For dietary components that are not excreted in the urine to any appreciable extent, e.g. sugars and fats, these ratios are virtually the same as digestibility ratios. These quantities were calculated for each bird separately.

Chemical analyses. With the exception of ornithurates and urea the analyses were done using methods described by Moss \& Parkinson (1972). Ornithurates and urea were extracted together from the droppings with industrial methylated spirit (Methylating Co. Ltd, Ardwick Green, Manchester). The extract was purified on a column of powdered cellulose (Whatman coarse grade; Reeve Angel \& Co., $1_{4}$ New Bridge St, London $\left.\mathrm{EC}_{4}\right)$ in aqueous ethanol $(500 \mathrm{ml} / \mathrm{l})$. Thin-layer chromatography was done using a $0.25 \mathrm{~mm}$ layer of microcrystalline cellulose (Merck, Anderman \& Co., Central Ave, East Mosely, Surrey) on aluminium cooking foil, supported on glass plates. The developing solvent was $n$-propanol-ammonia solution (sp. gr. 0.88$)(7: 3, v / v)$ (Baldwin, Robinson \& Williams, 1960). The ornithurates and urea were located under ultraviolet light and their position confirmed by spraying with a solution of $5 \mathrm{~g}$ $p$-dimethylaminocinnamaldehyde/l acetic anhydride (Baldwin et al. 1960) followed by heating at $120^{\circ}$ for $2 \mathrm{~min}$.

Two different methods were used for estimating ornithurate: (a) reflectance densitometry was done using a Chromoscan densitometer (Joyce Loebl \& Co., Princesway, Team Valley, Gateshead) and $(b)$ the ornithurate spots were removed from the foil and the total nitrogen content determined by Kjeldahl digestion. Method $(b)$ was also used for urea. The two methods for measuring ornithurates gave similar results, reproducible within $\pm 10 \%$ of the mean.

\section{RESULTS}

\section{Chemical composition of food and droppings}

The chemical compositions of food and droppings are given in Table r. Bulbils were relatively rich in protein ( $180 \mathrm{~g}$ crude protein $(\mathrm{N} \times 6.25) / \mathrm{kg} \mathrm{DM})$ and phosphorus $(4.2 \mathrm{~g} / \mathrm{kg} \mathrm{DM})$ and contained little lignin $(80 \mathrm{~g} / \mathrm{kg} \mathrm{DM})$. They resembled small, soft, huskless cereal grains in general appearance, chemical composition and moisture content and when milled they gave a fine flour. The two species of berries were both purple and contained high levels of moisture and soluble carbohydrate, but differed in other respects. Empetrum berries were packed with small seeds, had little juicy flesh, and contained relatively large amounts of lignin but remarkably little crude protein $(26 \mathrm{~g} / \mathrm{kg} \mathrm{DM})$ and $\mathrm{P}(0.87 \mathrm{~g} / \mathrm{kg} \mathrm{DM})$. Vaccinium berries had relatively few, large seeds, were very fleshy and contained little lignin. They contained more crude protein $(69 \mathrm{~g} / \mathrm{kg} \mathrm{DM})$ and P ( $1.6 \mathrm{~g} / \mathrm{kg} \mathrm{DM})$ than the Empetrum berries but less than the bulbils.

The caecal droppings from bulbils formed about one-quarter of the excrement on a 


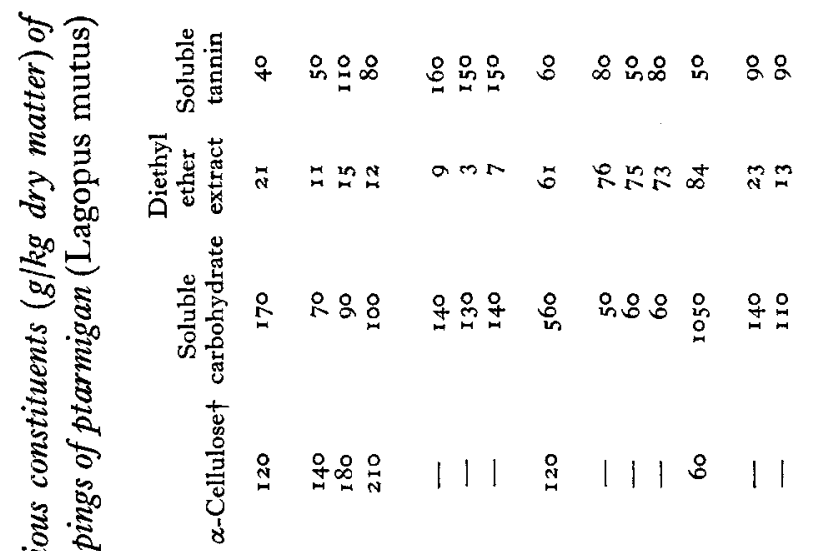

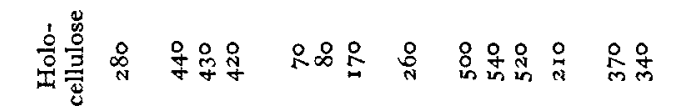

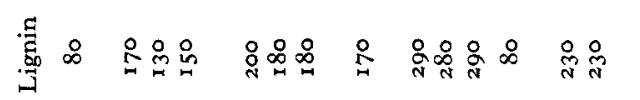

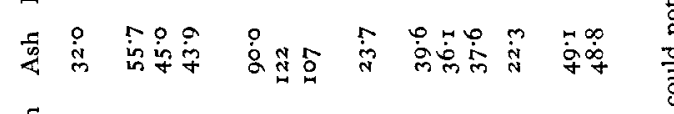

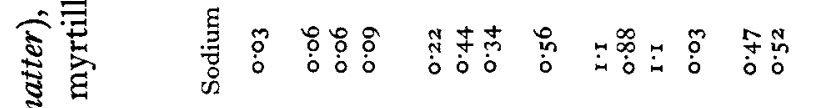
\&

妾

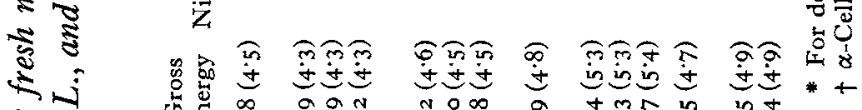

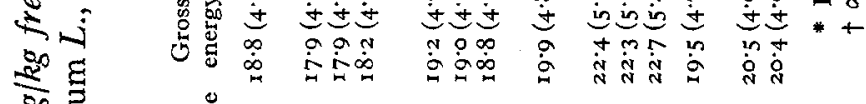

事营

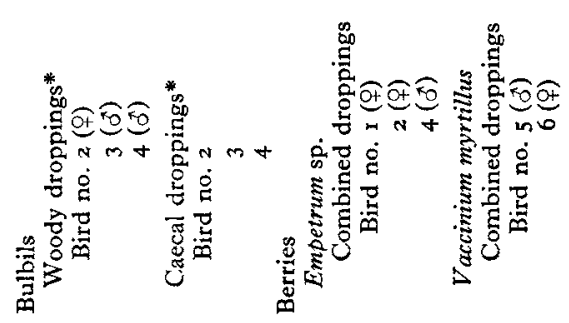


Table 2. Body-weight $(\mathrm{g})$ and dry matter (DM) intake and output $(\mathrm{g} / \mathrm{d})$ of ptarmigan (Lagopus mutus) given bulbils of Polygonum viviparum L. or berries of Empetrum sp. or Vaccinium myrtillus $L$.

\begin{tabular}{|c|c|c|c|c|}
\hline & DM intake & DM output & Initial body-wt & $\begin{array}{c}\text { Body-wt loss } \\
(\mathrm{g} / \mathrm{d})\end{array}$ \\
\hline \multicolumn{5}{|l|}{ Bulbils } \\
\hline Bird no. 2 & $32 \cdot 7$ & $16.2(0.27)^{*}$ & 470 & 0 \\
\hline 3 & $35 \cdot 7$ & $17 \cdot 3(0.22)^{*}$ & 455 & $\circ$ \\
\hline 4 & $35 \cdot 9$ & $18.0(0.26)^{*}$ & 435 & $\mathbf{o}$ \\
\hline \multicolumn{5}{|l|}{ Berries: } \\
\hline Bird no. I & $28 \cdot 8$ & $15 \cdot 3$ & 415 & 4 \\
\hline 2 & $30 \cdot 6$ & $15 \cdot 6$ & 425 & 5 \\
\hline 4 & $35 \cdot 8$ & $18 \cdot 0$ & 435 & 5 \\
\hline \multicolumn{5}{|c|}{ Vaccinium myrtillus } \\
\hline Bird no. 5 & $26 \cdot 6$ & $9 \cdot 22$ & 505 & I \\
\hline 6 & 20.2 & $7 \cdot 12$ & 460 & 4 \\
\hline
\end{tabular}

* Minimum proportion of the total formed by the caecal droppings; a small proportion was inextricably mixed with the woody droppings.

dry-weight basis (Table 2). Their chemical composition was different from that of the woody droppings; the caecal droppings containing proportionately less fat and holocellulose but more lignin, soluble carbohydrate, $\mathrm{N}$ and minerals, especially sodium.

Results from the organic analyses for berries must be regarded with caution, because the techniques were developed for use with widely different materials. In particular, the soluble carbohydrate content of Vaccinium berries could not have been $1050 \mathrm{~g} / \mathrm{kg}$ DM (Table I). Soluble carbohydrate was estimated by a colorimetric method using glucose as a standard; it seems likely that the carbohydrates in Vaccinium berries developed a more intense colour per unit weight than glucose.

\section{Retention of energy and organic constituents}

The retention ratios for DM in bulbils (0.50-0.53) and Empetrum berries (0.490.50 ) were similar, but the bulbils were a better source of metabolizable energy (ME) (Table 3). There was a difference in ME because Empetrum berries contained very little protein and the crude fat (diethyl ether extract) was relatively poorly digested. The crude fat in Vaccinium berries, however, was relatively well digested as was the DM (0.65). Presumably as a result, ME was also relatively high.

Soluble carbohydrate was digested well in all foods. In the instance of Empetrum berries, holocellulose, lignin, crude fat and crude protein $(\mathrm{N} \times 6.25)$ were either poorly digested, or present in small quantities in the food (Tables $I$ and 3 ). Hence soluble carbohydrate was the main constituent digested. This was not true with Vaccinium berries and bulbils, in which holocellulose and crude fat were both digested quite well.

\section{Nutrient balances and weight losses}

The initial loss of weight by birds eating bulbils was reversed by providing a $0 . \mathrm{I} \mathrm{M}-\mathrm{NaCl}$ solution, and was therefore probably caused by lack of sodium or chlorine. 
Table 3. Metabolizable energy (ME) $(k f(k c a l) / g)$ and retention ratios for various constituents of bulbils of Polygonum viviparum L. and berries of Empetrum sp. and Vaccinium myrtillus L. fed to ptarmigan (Lagopus mutus)

\begin{tabular}{|c|c|c|c|c|c|c|c|}
\hline & ME & $\begin{array}{l}\text { Dry } \\
\text { matter }\end{array}$ & Lignin & Holocellulose & $\begin{array}{c}\text { Soluble } \\
\text { carbohydrate }\end{array}$ & $\begin{array}{c}\text { Diethyl } \\
\text { ether } \\
\text { extract }\end{array}$ & $\begin{array}{c}\text { Soluble } \\
\text { tannin }\end{array}$ \\
\hline \multicolumn{8}{|l|}{ Bulbils } \\
\hline Bird no. 2 & $9 \cdot 7(2 \cdot 3)$ & 0.53 & -0.04 & 0.40 & 0.65 & 0.75 & 0.02 \\
\hline 3 & $10.0(2 \cdot 4)$ & 0.52 & 0.14 & $0 \cdot 39$ & 0.66 & 0.72 & -0.45 \\
\hline 4 & $9 \cdot 6(2 \cdot 3)$ & 0.50 & 0.01 & 0.36 & 0.62 & 0.69 & -0.13 \\
\hline \multicolumn{8}{|l|}{ Berries } \\
\hline Bird no. I & $8 \cdot 0(1.9)$ & 0.49 & 0.09 & -0.01 & 0.97 & 0.34 & 0.29 \\
\hline 2 & $8 \cdot 5(2 \cdot 0)$ & 0.49 & 0.16 & -0.06 & 0.94 & 0.37 & $0.5^{8}$ \\
\hline 4 & $8 \cdot 5(2 \cdot 0)$ & 0.50 & 0.14 & -0.01 & 0.95 & 0.43 & 0.33 \\
\hline \multicolumn{8}{|c|}{ Vaccinium myrtillus } \\
\hline Bird no. 5 & $12 \cdot 4(3 \cdot 0)$ & 0.65 & o & 0.39 & 0.95 & 0.90 & 0.33 \\
\hline 6 & $12 \cdot 3(2 \cdot 9)$ & 0.65 & o & 0.43 & 0.06 & 0.94 & 0.25 \\
\hline
\end{tabular}

Table 4. Nutrient balance (mg/d) for ptarmigan (Lagopus mutus) given bulbils of Polygonum viviparum $L$. or berries of Empetrum sp. or Vaccinium myrtillus $L$.

(Values in parentheses are the corresponding retention ratios)

\begin{tabular}{|c|c|c|c|c|c|c|}
\hline & Nitrogen & Phosphorus & Calcium & Magnesium & Potassium & Sodium \\
\hline \multicolumn{7}{|l|}{ Bulbils } \\
\hline Bird no. 2 & $+88(0.09)$ & $+0.1(0)$ & $-8.5(-0.23)$ & $+0.3(0)$ & $+I(0)$ & - \\
\hline 3 & $+95(0.09)$ & $-0.6(0)$ & $-8 \cdot 0(-0.24)$ & $+0.9(0)$ & $+12(0.04)$ & - \\
\hline 4 & $+140(0.14)$ & $+0.1(0)$ & $-15.0(-0.25)$ & $+5.4(0.06)$ & $+39(0.12)$ & - \\
\hline \multicolumn{7}{|l|}{ Berries } \\
\hline Bird no. 1 & $\begin{array}{l}-63(-0.52) \\
-89(-0.69) \\
-49(-0.33)\end{array}$ & $\begin{array}{r}-5.6(-0.22) \\
-10.8(-0.41) \\
-6.6(-0.21)\end{array}$ & $\begin{array}{r}-9.6(-0.35) \\
-I I .8(-0.4 I) \\
-6.1(-0.17)\end{array}$ & $\begin{array}{l}-0.6(-0.04) \\
-0.3(-0.02) \\
+0.1(0)\end{array}$ & $\begin{array}{l}+11(0.05) \\
+22(0.09) \\
+44(0.16)\end{array}$ & $\begin{array}{l}-0.8(-0.05) \\
-0.1(-0.01) \\
-0.1(-0.01)\end{array}$ \\
\hline \multicolumn{7}{|c|}{ Vaccinium myrtillus } \\
\hline Bird no. 5 & $\begin{array}{l}+35(0.12) \\
+30(0.14)\end{array}$ & $\begin{array}{l}+2.8(0.07) \\
+1.7(0.05)\end{array}$ & $\begin{array}{l}-18(-\mathrm{I} \cdot 04) \\
-22(-\mathrm{I} \cdot 65)\end{array}$ & $\begin{array}{l}-0.3(-0.02) \\
-0.5(-0.05)\end{array}$ & $\begin{array}{l}-4(-0.02) \\
-1(-0.01)\end{array}$ & $\begin{array}{l}-3.5(-4.42) \\
-3.2(-5.27)\end{array}$ \\
\hline
\end{tabular}

This is not surprising as the bulbils contained only $0.03 \mathrm{~g} \mathrm{Na} / \mathrm{kg} \mathrm{DM}$. N retention continued during the trials even though the birds' weight remained constant (Table 4.)

Vaccinium berries also contained $0.03 \mathrm{~g} \mathrm{Na} / \mathrm{kg} \mathrm{DM} ; \mathrm{NaCl}$ solution was not provided and losses of $\mathrm{Na}$ were about five times greater than intake (Table 4), and the birds lost weight. Other, relatively small, losses of minerals also occurred but $\mathrm{N}$ was not lost.

Empetrum berries, however, contained twenty times as much $\mathrm{Na}$ as the other two foods but only $4.2 \mathrm{~g} \mathrm{~N} / \mathrm{kg}$. On balance, the birds given this diet lost $\mathrm{N}$, as well as some minerals, and also lost weight at the rate of $4^{-5} \mathrm{~g} / \mathrm{d}$.

\section{$N$ metabolism}

Urates formed only $12 \%$ of the total $\mathrm{N}$ present in the woody droppings from birds given bulbils. Some of the remaining $\mathrm{N}$ was present in the form of ammonium-N 
Table 5. Amounts of nitrogen and nitrogenous compounds ( $\mathrm{g} / \mathrm{kg}$ dry matter) in food and droppings of ptarmigan (Lagopus mutus) given bulbils of Polygonum viviparum L. or berries of Empetrum sp. or Vaccinium myrtillus $L$.

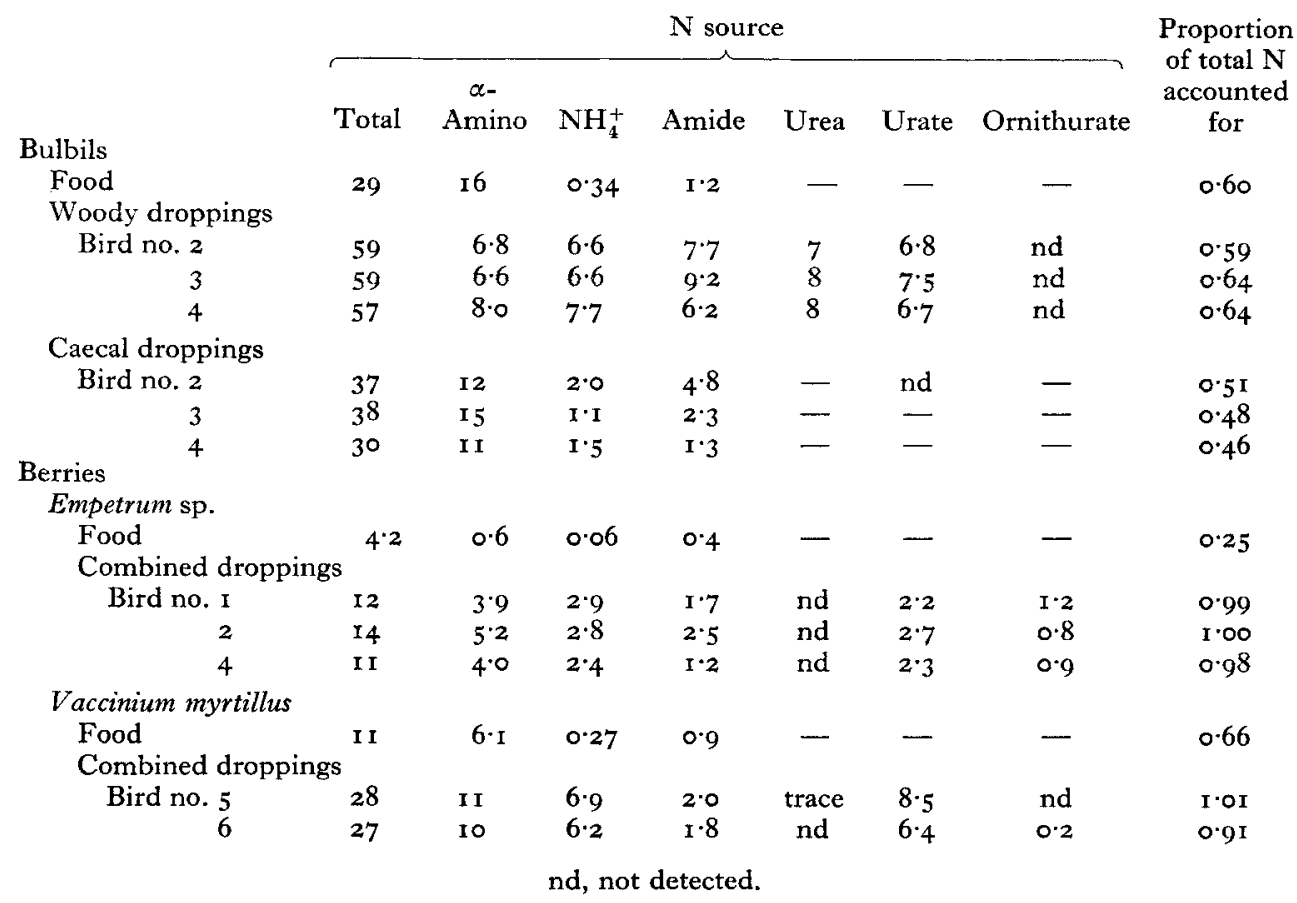

( $12 \%$ of total), urea ( $13 \%$ ) and $\alpha$-amino-N (12\%). Of the total $N$, half was undetermined. We attempted to measure creatine and creatinine, but the method was unsatisfactory with this material and the only conclusion that could be drawn was that less than $\mathrm{I} \%$ of the $\mathrm{N}$ in the woody droppings was present as creatine and creatinine.

Most of the $\mathrm{N}$ in droppings from both kinds of berries was accounted for, largely as $\mathrm{NH}_{4}^{+}-\mathrm{N}$, urates and $\alpha-\mathrm{NH}_{2}-\mathrm{N}$ with either no urea, or only a trace amount. Less than $2 \%$ of the $\mathrm{N}$ was present as creatine and creatinine. Droppings from Empetrum berries also contained ornithurates in significant quantities (Table 5).

\section{DISCUSSION}

Gut lengths of captive tetraonids

The present work, and that of Moss \& Parkinson (1972) on red grouse, was done using captive birds. These birds have much shorter guts than wild birds (Moss, 1972). The results of these two studies should not, therefore, be extrapolated to wild birds until more information is available about them. 
Table 6. Holocellulose (and $\alpha$-cellulose): lignin ratios for bulbils of Polygonum viviparum and droppings of ptarmigan (Lagopus mutus) fed on bulbils

\begin{tabular}{rccc} 
& & \multicolumn{2}{c}{ Droppings } \\
Bird no. 2 & Bulbils & Woody & Caecal \\
3 & $3 \cdot 5(\mathrm{r} \cdot 5)$ & $2 \cdot 6(0 \cdot 8)$ & 0.4 \\
4 & - & $3 \cdot 3(\mathrm{r} \cdot 4)$ & 0.4 \\
Mean & - & $2 \cdot 8(\mathrm{I} \cdot 4)$ & 0.9 \\
& $3 \cdot 5(\mathrm{I} \cdot 5)$ & $2 \cdot 9(\mathrm{r} \cdot 2)$ & 0.6
\end{tabular}

\section{Role of caecums}

The chemical composition of the caecal droppings derived from bulbils was quite different from that of the woody droppings, indicating that the metabolic activities taking place in the caecums were different from those in the small intestine. No urates were detected in the caecal droppings, hence the urine was excreted along with the woody droppings. This would explain the high levels of $\mathrm{N}$ in the woody droppings (Table I).

The holocellulose:lignin ratio was similar in the bulbils and the woody droppings but was markedly lower in the caecal droppings (Table 6). Lignin was not digested (Table 3). This suggests that holocellulose digestion occurred largely in the caecums and this is therefore similar to the situation in red grouse eating heather (Moss \& Parkinson, 1972). Also similar was the composition of the caecal droppings with their relatively low crude-fat (diethyl ether extract), high soluble-tannin and high solublecarbohydrate contents. The same explanations may also be offered: (a) that much fat had been absorbed in the small intestine before the more liquid fraction of the chyme entered the caecums, $(b)$ soluble tannins may have been relatively inert in the caecums and became increasingly concentrated as more labile substances were digested and (c) part of the soluble carbohydrate in the caecal droppings may have derived from bacterial remains.

\section{Energy metabolism and weight losses}

The mean daily intakes of ME were 340,265 and $235 \mathrm{~kJ} / \mathrm{d}(8 \mathrm{I}, 63$ and $56 \mathrm{kcal} / \mathrm{d}$ ) respectively with bulbils, Empetrum and Vaccinium berries. However, some birds lost weight. It is reasonable to assume that this was due to catabolism of muscle protein, because ptarmigan have very small reserves of fat (Moss, unpublished results), and so I $g$ weight lost would provide about $15 \mathrm{~kJ}$. This would increase the amount of energy available to $34^{\circ}, 34^{\circ}$ and $33^{\circ} \mathrm{kJ} / \mathrm{d}$ when feeding on bulbils, Empetrum and Vaccinium berries respectively. This compares with a resting metabolic rate of $295 \mathrm{~kJ} / \mathrm{d}(7 \mathrm{r} \mathrm{kcal} / \mathrm{d})$ at thermal neutrality (West, 1972$)$, and $420 \mathrm{~kJ} / \mathrm{d}$ (100 kcal/d) for free-living rock ptarmigan in winter in Alaska (Moss, 1973).

Vaccinium berries contained only $0.03 \mathrm{~g} \mathrm{Na} / \mathrm{kg}$ DM. The birds eating berries lost about five times the quantity of $\mathrm{Na}$ they took in. The same concentration was found in bulbils, and birds given bulbils also lost weight until $\mathrm{NaCl}$ was provided. Hence lack of $\mathrm{Na}$ may have caused the birds to lose weight when eating Vaccinium berries. However, this seems unlikely with Empetrum berries, which contained twenty times 
as much $\mathrm{Na}$ as the other two foods, but very little protein. This, together with the fact that the birds were in negative $\mathrm{N}$ balance, suggests that lack of protein may have caused the ptarmigan to lose weight when eating Empetrum berries.

\section{$N$ metabolism}

Although all the $\mathrm{N}$ in the droppings derived from berries was accounted for, much of the $\mathrm{N}$ in the droppings from bulbils and in all three foods was undetermined (Table 5). About $80 \%$ of the $\mathrm{N}$ in most vegetable proteins is present as $\alpha-\mathrm{NH}_{2}-\mathrm{N}$ (Block \& Weiss, 1956). Recoveries of $\alpha-\mathrm{NH}_{2}-\mathrm{N}$ were therefore less than $100 \%$ on the assumption that most of the $\mathrm{N}$ in the foods was present as protein. High levels of carbohydrate, especially reducing sugars, are known to reduce $\alpha-\mathrm{NH}_{2}-\mathrm{N}$ recoveries (Block \& Weiss, 1956) and the foods did contain much soluble carbohydrate (Table I).

It is, however, doubtful whether poor $\alpha-\mathrm{NH}_{2}-\mathrm{N}$ recoveries can explain the large amount of undetermined $\mathrm{N}$ in the droppings from the bulbils. These contained less soluble carbohydrate than the bulbils themselves and so $\alpha-\mathrm{NH}_{2}-\mathrm{N}$ recoveries should have been higher. We noticed that the woody droppings from bulbils contained much white material which looked like uric acid and were surprised at the low concentrations of urates actually present (Table 5). It seems probable that the white material was not entirely uric acid.

Chickens usually excrete $70-80 \%$ of digested $\mathrm{N}$ as urates and $15-20 \%$ as $\mathrm{NH}_{4}^{+}-\mathrm{N}$, with very small amounts of urea $(\mathrm{I}-2 \%$ ) and creatine plus creatinine (about $2 \%$ ). This applies at high and low levels of protein intake (Bolton, 1957; Tasaki \& Okumura, 1964). When fed benzoic acid, chickens excrete ornithuric acid as a detoxication product (Baldwin et al. 1960). The picture is rather different for tetraonids.

Consider birds which were not losing $\mathrm{N}$ on balance. Red grouse eating heather (Io $\mathrm{g} \mathrm{N} / \mathrm{kg}$ DM) excreted very little of their digested $\mathrm{N}$ as urates, but most as $\mathrm{NH}_{4}^{+}-\mathrm{N}$ and ornithurates (Moss \& Parkinson, 1972). Rock ptarmigan eating Vaccinium berries ( $\mathrm{I} \mathrm{g} \mathrm{N} / \mathrm{kg} \mathrm{DM})$ produced very little ornithuric acid, therefore sparing ornithine; in this instance about half the metabolized $\mathrm{N}$ was excreted as urates and half as $\mathrm{NH}_{4}^{+}-\mathrm{N}$. Rock ptarmigan eating bulbils $(29 \mathrm{~g} \mathrm{~N} / \mathrm{kg} \mathrm{DM})$ did not excrete more $\mathrm{NH}_{4}^{+}-\mathrm{N}$ or urates than birds given Vaccinium berries, but instead produced urea $(13 \%$ of total $\mathrm{N}$ in droppings) and other, unidentified, compounds. Generalizing, tetraonids excrete more $\mathrm{NH}_{4}^{+}-\mathrm{N}$ and urea and less urates than chickens; at high levels of protein intake they excrete much of the presumably metabolized $\mathrm{N}$ in an unidentified form.

However, catabolized tissue- $\mathrm{N}$ does seem to be excreted largely as urates; the proportion has been estimated as $70 \%$ for red grouse losing weight on a diet of heather (Moss, 1967).

Ptarmigan eating Empetrum berries and red grouse eating heather both excreted ornithurates and both apparently digested lignin and soluble tannins. Ptarmigan eating Vaccinium berries apparently digested some soluble tannins but no lignin, and one bird produced a trace of ornithurates. Birds on bulbils digested neither lignin nor soluble tannins and produced no ornithurates. The values for digestion of soluble tannins may be questioned, as a colorimetric method employing tannic acid as standard was used to estimate tannins and the retention was apparently less than zero 
with the bulbils. None the less, these associations suggest that the benzoic acid part of the ornithuric-acid molecule may have been partly derived from the digestion of lignin or tannins or both, as well as the prolignins suggested by Martin (1969) in the instance of sheep producing hippuric acid.

\section{Food preferences of wild ptarmigan}

Except for their low $\mathrm{Na}$ content, bulbils were clearly a good food for ptarmigan, being a relatively good source of energy and protein. It is not surprising that they are a favourite food of ptarmigan in Iceland and may form over $80 \%$ of the summer diet (Gardarsson \& Moss, 1970). Lack of $\mathrm{Na}$ is not likely to be important in the wild as other foods containing more $\mathrm{Na}$ are readily available.

Empetrum berries, on the other hand, were a good source of soluble carbohydrate but little else. Although they are favoured by ptarmigan in Iceland, they are invariably eaten along with other foods which presumably provide the necessary protein (Gardarsson \& Moss, I970).

Vaccinium berries are relatively scarce in Iceland, but in the Cairngorm mountains of Scotland are more abundant than Empetrum berries in autumn. By late spring, however, more Empetrum berries usually remain, suggesting that the Vaccinium berries are preferred by the ptarmigan, red grouse and thrushes. This is in accord with the results in this paper, which show that Vaccinium berries are a better food than Empetrum berries, being an adequate source of protein as well as being more digestible.

We thank S. E. Allen and other colleagues in the Chemical Service of the Institute of Terrestrial Ecology for doing many of the analyses and criticizing the manuscript, and A. Gardarsson for providing the bulbils and Empetrum berries.

\section{REFERENCES}

Baldwin, B. C., Robinson, D. \& Williams, R. T. (1960). Biochem. F. 76, 595.

Block, R. J. \& Weiss, K. W. (I956). Amino Acid Handbook. Springfield, Ill.: C. C. Thomas.

Bolton, W. (1957). F. Sci, Fd Agric. 8, 132.

Gardarsson, A. \& Moss, R. (1970). In Animal Populations in Relation to their Food Resources p. 47 [A. Watson, editor]. Oxford and Edinburgh: Blackwell Scientific Publications.

Gelting, P. (1937). Meddr Grønland 116, III.

Martin, A. K. (r969). Proc. Nutr. Soc. 28, 65A.

Moss, R. (1967). Aspects of grouse nutrition. PhD Thesis, University of Aberdeen.

Moss, R. (1969). Avicult. Mag. 75, 256.

Moss, R. (1972). F. Wildl. Mgmt 36, 99.

Moss, R. (1973). Condor 75, 293.

Moss, R. \& Parkinson, J. A. (1972). Br. F. Nutr. 27, 285.

Tasaki, I. \& Okumura, J. (1964). F. Nutr. 83, 34 .

Watson, A. (1964). Scott. Nat. 7r, 60.

West, G. C. (1972). Comp. Biochem. Physiol. 42A, 867.

Wilson, E. A. (I91 I). The Grouse in Health and in Disease, Being the Final Report of the Committee of Enquiry on Grouse Disease p. 67. London: Elder. 